Edukids volume 16 (2) tahun 2019

EDUKIDS: Jurnal Pertumbuhan, Perkembangan, dan Pendidikan Anak Usia Dini

Jln. Dr. Setiabudhi No. 229 Kota Bandung 40154. e-mail: edukid@upi.edu website: http://ejournal.upi.edu/index.php/edukid

\title{
PENYELENGGARAAN PENDIDIKAN INKLUSIF DI LEMBAGA PAUD
}

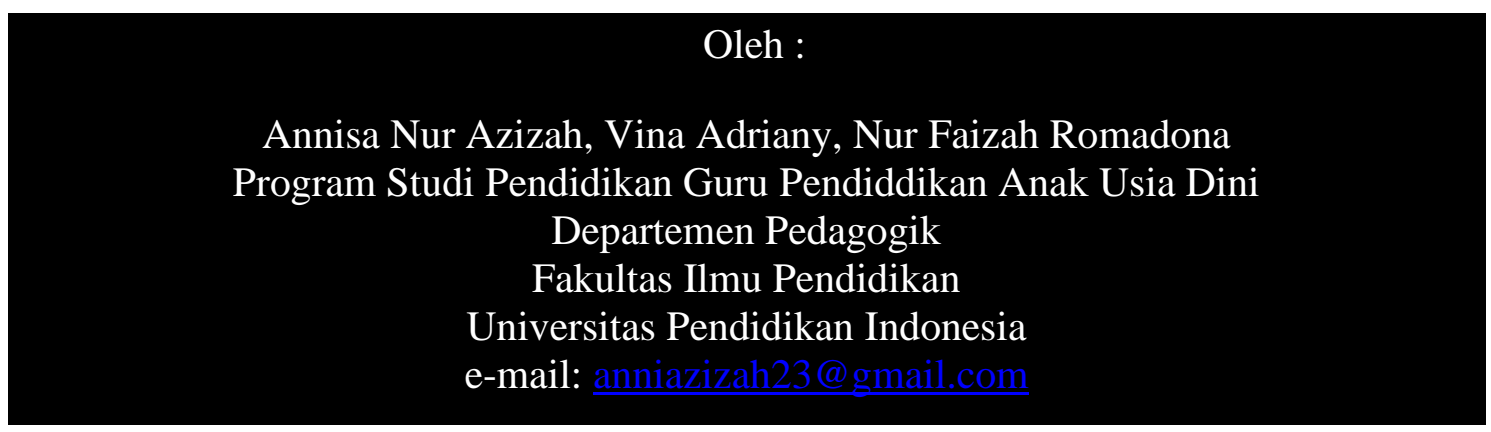

Abstrak: Penelitian ini dilatarbelakangi oleh jumlah ABK yang semakin meningkat dan penyelenggaraan pendidikan inklusi di lembaga PAUD yang masih sedikit serta penelitian terdahulu yang masih sangat terbatas. Tujuan penelitian ini untuk mengetahui penanganan ABK di PAUD berbasis alam. Penelitian ini menggunakan pendekatan kualitatif dengan desain penelitian studi kasus. Teknik pengumpulan data dilakukan melalui wawancara pada tiga partisipan yaitu: kepala sekolah, fasilitator kelas, dan GPK. Analisis data menunjukkan adanya permasalahan dalam menyelenggarakan pendidikan inklusi yaitu: fasilitas dan SDM yang belum tersedia termasuk dana dalam salary untuk shadow teacher dilakukan oleh orangtua dan ekgiatan evaluasi yang belum terlaksana akibat kendala lainnya. Lalu adanya tantangan dalam menangani ABK yaitu: kebutuhan ABK sesuai dengan kemampuan ABK (anak mampu latih dan anak mampu didik), kerjasama orangtua yang diatasi dengan melakukan komunikasi yang baik untuk menyampaikan program khusus yang dimiliki dan melibatkan orangtua untuk komitmen dalam membantu penangan dan terakhir tantangan dalam merekrut SDM yang siap dengan memberikan pembinaan berupa pelatihan oleh psikolog dan kegiatan parenting . Selain itu adanya penanganan ABK dengan metode green tehrapy yaitu kegiatan berkaitan dengan fasilitas alam namun belum sepenuhnya berkaitan dengan alam. Dan adanya pemberian stimulus selama 24 jam yang dilakukan selama di sekolah maupun di rumah dengan melibatkan orangtua. Dan treatment selanjutnya dengan memberikan kesempatan pada ABK untuk belajar dalam satu kelas yang sama dengan anak pada umunya.

\section{Kata kunci: PAUD, Inklusi}

Abstract: This research is motivated by the ever increasing number of special need children and the implementation of inclusive education in early childhood education institutions as well as very limited prior research. The purpose of this study was to determine the handling of need children in nature-based early childhood education. This research uses a qualitative approach with a case study research design. Data collection techniques were carried out through interviews with three participants, namely: the principal, class facilitator, and shadow teacher. The Data analysis shows that there are problems in conducting inclusive education, namely: facilities and human resources that are not yet available, including funds in salaries for shadow teachers conducted by 
parents and evaluation activities that have not been carried out due to other obstacles. Then there are challenges in dealing with need children namely: need children needs in accordance with $A B K$ abilities (children able to train and children able to educate), parental cooperation is overcome by conducting good communication to deliver special programs that are owned and involve parents for commitment to help in handling and finally challenges in recruiting shadow teacher who are ready by providing coaching in the form of training by psychologists and parenting activities. In addition, the handling of $A B K$ with the green tea method is an activity related to natural facilities but not yet fully related to nature. And there is a 24-hour stimulus provided during school and at home with parents involved. And the next treatment is by giving ABK the opportunity to learn in the same class with children in general.

\section{Keywords: Early Chilhood Education, Inclusion}

\section{PENDAHULUAN}

Setiap tahun kebutuhan pendidikan untuk anak berkebutuhan khusus (ABK) semakin meningkat, mengingat semakin banyaknya jumlah ABK. Menurut CNN Indonesia (2017) jumlah $\mathrm{ABK}$ di Indonesia mencapai angka 1,6 juta anak, hal ini setara dengan $0,75 \%$ data akhir (Badan Pusat Statistik/BPS, 2016). Dengan jumlah ABK yang terus bertambah namun keberadaan SLB yang masih sangat terbatas terutama pada daerah-daerah tertentu dikarenakan keberadaan SLB yang berada di kabupaten/kota dengan jumlah 514 kabupaten/kota, 62 diantaranya belum memiliki SLB, namun agar pendidikan merata termasuk untuk ABK maka muncullah pendidikan inklusif untuk daerah-daerah dengan sekolah reguler namun menjadi penyelenggara pendidikan inklusif dan telah terdaftar sebanyak 32 ribu sekolah reguler yang menjadi sekolah inklusi di berbagai daerah. Sehingga dari jumlah 1,6 juta ABK 18 persen diantaranya baru mengenyam pendidikan, dengan 115 ribu ABK bersekolah di SLB dan 299 ribu ABK bersekolah pada lembaga pendidikan penyelenggara pendidikan inklusif (Maulipaksi, 2017). Sejalan dengan UU No 20 tahun (2003), Pasal 5 menyatakan bahwa "Setiap warga negara mempunyai hak yang sama untuk mengeyam pendidikan, dan warga Negara yang memiliki kelainan fisik, emosional, intelektual, mental dan/atau sosial berhak memperoleh pendidikan khusus".

Dalam Peraturan Menteri Pendidikan Nasional No. 70 Tahun 2009 Pasal (1) tentang Pendidikan Inklusif bagi peserta didik yang memiliki kelainan dan memiliki potensi kecerdasan dan/atau bakat istimewa bahwa:

Pendidikan inklusif merupakan sistem penyelenggaraan pendidikan kepada semua peserta didik yang memiliki kelainan dan memiliki potensi kecerdasan dan/bakat istimewa untuk mengikuti pendidikan aau pembelajaran dalam satu lingkungan pendidikan secara bersama-sama dengan peserta didik pada umumnya. bersama-sama dengan peserta didik pada umumnya.

Secara formal pendidikan inklusif ditegaskan dalam pernyataan Salamanca pada Konferensi dunia tentang Pendidikan Khusus tahun 1994 yang menyatakan bahwa "Prinsip mendasar dari pendidikan inklusif adalah: selama memungkinkan, semua anak seyogyanya belajar bersama-sama tanpa memandang kesulitan, ataupun perbedaan yang mungkin ada pada mereka" (UNESCO, 1994).

Tidak hanya jenjang pendidikan dasar dan menengah, namun pemerintah Indonesia telah memfasilitasi keberadaan ABK sejak usia dini. Hal ini telah dituangkan pemerintah pada Peraturan Pemerintah No. 60 Tahun 2010 tentang 
Pengelolaan dan Penyelenggaraan Pendidikan pasal 132 yaitu "Pendidikan khusus bagi peserta didik berkelainan pada jalur formal diselenggarakan melalui satuan pendidikan anak usia dini, satuan pendidikan dasar, dan satuan pendidikan menengah". Layanan pendidikan untuk ABK di PAUD dituangkan dalam Peraturan Menteri Pendidikan dan Kebudayaan No. 146 Tahun 2014 tentang kurikulum PAUD dan Peraturan Presiden No. 60 Tahun 2013 tentang pengembangan PAUD holistic integratif. Pelayanan ini juga bersifat nondiskriminatif sehingga seluruh anak usia dini dilayani tanpa terkecuali termasuk ABK.

Menurut Kustawan (2012, hlm. 49), satuan pendidikan yang akan menyelenggarakan pendidikan inklusif perlu memenuhi persyaratan diantaranya ijin operasional, mampu merancang dan menggunakan kurikulum fleksibel, tersedianya pendidik dan tenaga kependidikan yang memiliki kualifikasi akademik yang sesuai dengan prosedur operasi standar, tersedia sarana dan prasarana yang memadai, sumber dana yang menjamin kelangsungan penyelenggara pendidik dan mendapat rekomendasi penerapan sebagai sekolah penyelenggaraan pendidikan inklusif.

Realitasnya, belum semua sekolah reguler menjadi sekolah inklusif dikarenakan berbagai alasan seperti ketidaksiapan pihak sekolah maupun pendidik akan penyelenggaraan pendidikan inklusif. Seperti dalam penelitian yang dilakukan oleh Sopa (2017) dan Tarnoto (TT) bahwasannya pada tingka sekolah dasar banyak permsalahan dalam menyelenggarakan sekolah inklusif diantaranya; belum tersedianya guru pembimbing khusus (GPK), kurang tersedia anggaran, ABK masih tersisihkan karena berbagai pihak yang belum dapat menerima keberadaannya, kurangnya kompetensi guru dalam menangani ABK, kurangnya kepedulian orangtua terhadap ABK, jumlah siswa ABK dalam satu kelas lebih mendominasi, dan kurangnya kerjasama dari berbagai pihak seperti masyarakat, ahli profesional dan pemerintah.

Tidak hanya di Indonesia namun di beberapa negara pun seperti di Skotlandia dalam penelitian Florian (2008) yang menyatakan bahwasannya di Skotlandia, pihak sekolah maupun pendidik masih kebingungan dalam menyelenggarakan pendidikan inklusif. Meskipun kebijakan pemerintah telah mengharuskan untuk menjadi sekolah inklusif namun banyak kendala dalam menyelenggarakan pendidikan inklusif seperti salah satunya kurangnya pemahaman pendidik mengenai pendidikan inklusif. Seperti halnya dalam penelitian lain yang dilakukan oleh Lenakakis, dkk. (2018) di Yunani dan Hornby (2015) di Inggris, juga menunjukkan bahwasannya kesiapan guru sangat memempengaruhi. Sehingga adanya kesenjangan antara kebijakan pemerintah dengan penyelenggaraan sekolah inklusif.

Penelitian terdahulu pun lebih banyak membahas tugas guru pembimbing khusus (GPK) yang sudah terlaksana seperti dalam penelitian yang dilakukan oleh Indriwati (2013), Rahmaniar (2016), Firdaus (2016), Mulyani (2016), dimana semua penelitian tersebut dilakukan pada tingkat sekolah dasar dengan hasil yang sama yaitu GPK telah melakukan asesmen diawal, membuat program pendidikan individu (PPI), melakukan evasluasi, dan menyediakan alat pembelajaran khusus namun untuk koordinasi dengan guru kelas masih belum terlaksana.

Meskipun sudah terdapat banyak penelitian mengenai sekolah inklusif, akan tetapi sebagaimana yang telah dibahas oleh peneliti bahwa penelitian tersebut masih terfokus pada tingkat sekolah dasar (SD) keatas untuk penelitian di PAUD sendiri masih sangat terbatas. Oleh karena itu, peneliti tertarik 
untuk melakukan penelitian mengenai penanganan $\mathrm{ABK}$ di sekolah inklusif pada tingkat PAUD. Maka judul penelitian ini "PENYELENGGARAAN PENDIDIKAN INKLUSIF DI LEMABAGA PAUD".

\section{METODE}

Desain penelitian yang digunakan dalam penelitian ini adalah studi kasus dengan pendekatan kualitatif. Alasan peneliti memilih metode dan pendekatan tersebut dikarenakan sangat cocok dengan fokus masalah yang peneliti ambil, yaitu penangan terhadap ABK di PAUD inklusi dengan data yang diambil yaitu perbuatan dan ucapan atau perkataan dari responden. Creswell (2010) mendefinisikan studi kasus sebagai suatu eksplorasi dari sistemsistem yang terkait (bounded system) kasus.

Dalam penelitian ini, peneliti menggunakan teknik sampel purposive dengan memfokuskan pada informaninforman terpilih yang kaya dengan kasus untuk studi yang bersifat mendalam (Sukmadinata, 2007, hlm. 101). Subjek dalam penelitian ini yaitu kepala sekolah, guru kelas dan guru pembimbing khusus (GPK). Metode pengumpulan data menggunakan metode wawancara.

\section{HASIL DAN PEMBAHASAN}

Pada bab ini temuan dan pembahasan dari data yang sudah dikumpulkan kemudian dituliskan berdasarkan pada pengkategorisasian tema dari hasil analisis. Terdapat dua tema yang dibahas pada bab ini, yaitu: 1) Isu Penyelenggaraan Pendidikan Inklusif, 2) Treatment Anak Berkebutuhan Khusus.

\subsection{Isu Penyelenggaraan Pendidikan Inklusif}

Tema pertama yang dihasilkan dari analisis data penelitian ini adalah berbagai tantangan dalam penyelenggaraan pendidikan inklusif di

PAUD yang telah guru alami. Dalam tema ini, terdapat dua sub-tema berdasarkan kelompok tantangan tersebut, yaitu permasalahan menyelengarakan pendidikan inklusif dan tantangan guru dalam menangani ABK.

4.1.1

Penyelenggaraan inklusif

Dalam penyelenggaraan pendidikan inklusif yang telah dilakukan, ketiga guru berhadapan dengan isu berkaitan dengan fasilitas dan SDM yang siap.

Pertama fasilitas dan SDM kurang. Dalam kasus ibu $\mathrm{H}$ sebagai kepala sekolah, bahwa ketika menjabat sebagai kepala sekolah sekitar 4 tahun yang lalu pada saat itu pula sekolah tersebut menerima $\mathrm{ABK}$ namun masih belum mengetahui penanganan yang sesuai.

"Awalnya kita tidak secara mengumumkan gitu bahwa kita menerima anak-anak spesial, euu tapi itu karena waktu itu ada namanya Razan yang sekarang kelas 4 di sini juga dulu dari TK A, euu terus ibu nya bekerja ayahnya bekerja, euu terus kita merasa ini ada yang beda gitu dari diri anak ini satu dia tidak fokus terus di sisi lain dia tidak bisa berinteraksi dengan temannya dan kalo untuk dari segi fisik engga ada masalah gitu yah namun udah ketauan bahwa dia keterlambatan berbicara".

(Wawancara H, 22 Juni 2019)

“(...) akhirnya dari sana kita kan penasaran cara menanganinya itu kita mencari sendiri aja belum ada pendampingan khusus euu belum ada penanganan yang baik itu bagaimana gitu yah baru nyari-nyari sendiri."

(Wawancara H, 22 Juni 2019)

Pernyataan tersebut pun didukung oleh ibu M sebagai fasilitator kelas bahwa tanggung jawab ABK dipegang penuh oleh guru kelas dan belum mengetahui penanganan yang tepat. 
Dari pernyataan ibu $\mathrm{M}$ ini dapat diketahui bahwa jumlah siswa yang lebih banyak merupakan masalah dalam menyelenggarakan pendidikan inklusif. Astati, dkk. (2009) menyatakan hasil penelitiannya bahwa kelas yang memiliki jumlah guru lebih banyak indeks inklusinya lebih tinggi dibandingkan dengan kelas yang memiliki jumlah guru sedikit. Fenomena ini dapat dijelaskan bahwa dengan jumlah guru lebih dari satu menyebabkan perhatian khusus pada ABK lebih baik sehingga memungkinkan ABK dapat berpartisipasi dalam kegiatan belajar dan berpartisipasi secara optimal di kelas.

Sedangkan kebijakan pemerintah yang mengharuskan untuk sekolah umum menjadi sekolah inklusif seperti yang dicantumkan pada UU Nomor 23 Tahun 2002 tentang Perlindungan anak, khususnya pasal 51 yang berbunyi, "anak yang menyandang cacat fisik dan/atau cacat mental diberikan kesempatan yang sama dan aksesibilitas untuk memperoleh pendidikan biasa dan pendidikan luar biasa".

Pernyataan serupa juga diungkapkan oleh ibu $\mathrm{T}$ sebagai salah satu GPK yang ada bahwa fasilitas sekolah masih kurang, bahkan kertas sebagai media stimulus anak harus mengajukan terlebih dahulu.

Ketiga partisipan ini berbicara mengenai hal yang sama yaitu adanya permasalahan dalam fasilitas baik itu fasilitas dari pemerintah maupun fasilitas sekolah. Hal ini pun merupakan faktor yang tekait dengan kegiatan operasional di lapangan yang sampai saat ini masih rendah, minimnya dukungan fasilitas dan sumber daya yang tersedia menjadi kendala dalam impelementasi pendidikan inklusi untuk anak-anak usia dini (Suparno, 2010, hlm. 9).

Kedua, kendala ekonomi. Ibu $\mathrm{H}$ dan ibu M menyebutkan adanya masalah lain mengenai penyelenggaraan pendidikan inklusi ini, yaitu kendala ekonomi. Dimana dapat diketahui bahwa sekolah yang menerima ABK akan membutuhkan biaya yang lebih dikarenakan adanya pendampingan khusus dari sekolah namun keadaan orangtua $\mathrm{ABK}$ yang tidak bisa dikatakan semua diatas rata-rata. Sehingga beberapa orangtua $\mathrm{ABK}$ memilih untuk tidak menyekolahkan anaknya.

Namun dari data yang telah di analisis bahwa bukan hanya kendala ekonomi orangtua tapi pembiayaan yang dikeluarkan sekolah pun masih belum tersusun dimana seperti yang diungkapkan oleh ibu $\mathrm{H}$ bahwa guru pembimbing khusus (GPK) yang sering disebut shadow teacher/helper di sekolah tersebut merupakan karyawan orangtua yang dibantu sekolah sebagai jembatan dalam merekrut SDM tersebut sehingga dari segi salary diberikan murni oleh orangtua dan pihak sekolah hanya bertanggung jawab membina GPK tersebut.

Oleh karena itu kendala ekonomi orangtua dan salary GPK sangat berkaitan, dikarenakan untuk mendapatkan GPK yang sesuai dengan latar belakang pendidikan khusus maka perlu salary yang lebih sehingga dengan kendala ekonomi orangtua, GPK yang direkrut tidak sesuai dengan latar belakang pendidikannya. Namun fenomena di Indonesia untuk saat ini pada sekolah inklusif dana untuk penyelenggaraannya masih sangat terbatas namun pemerintah mewajibkan inklusif sehingga sekolah inklusif merekrut SDM non pendidikan khusus, selain jumlah SDM yang terbatas tapi kendala ekonomi keluarga pun menjadi perhatian penting. Selain itu bantuan penyelenggaraan PAUD inklusi dan TK Luar Biasa bersifat bantuan terbatas, sehingga belum semua lembaga PAUD Inklusi atau TK Luar Biasa mendapatkan dana.

Dari pertanyaan tersebut maka dapat dikatakan bahwa kendala ekonomi 
dalam menyelenggarakan pendidikan inklusif dimana keadaan ekonomi orangtua berkaitan terhadap salary GPK. Sehingga pembiayaan sekolah pun dalam hal penyediaan GPK masih dalam keterlibatan orangtua dalam penggajian atau salary yang diberikan. Seperti faktor-faktor yang harus dipertimbangkan dalam menyelenggarakan pendidikan inklusi menurut Johnsen, B.H. \& Skjorten, M.D. (2003, hlm. 52-58) salah satunya adalah kebijakan, hukum, undang-undang, ekonomi, yaitu perlunya ada undang-undang khusus yang mengakomodasi kepentingan ABK, serta dukungan dana dalam penyelenggaraannya.

Ketiga, evaluasi. Dari hasil wawancara terhadap tiga partisipan mengungkapkan adanya evaluasi baik itu evaluasi antar GPK dengan fasilitator kelas atau pun evaluasi lainnya yang memang sudah terjadwalkan, akan tetapi belum terlaksana sebagai mestinya. Dari ketiga guru mengungkapkan kegiatan evaluasi dilakukan berbeda-beda.

"Untuk evaluasi kita adasih, karna bulan-bulan ini teh kurang kondusif karena banyak acara sebenarnya sudah terjadwalkan 2 minggu sekali untuk evaluasi dengan shadow teacher"

(Wawancara H, 22 juni 2019)

\section{"Evaluasi diakhir. Euuu.. diakhir semester."}

(Wawancara T, 2 Juli 2019)

Dari kedua ungkapan tersebut terlihat bahwa evaluasi yang sudah terjadwalkan belum terlaksana karena untuk ungkapan ibu $\mathrm{H}$ menyatakan langsung bahwa evaluasi memang ada namun belum terlaksana karena berbagai hal dan untuk ibu $\mathrm{T}$ yang menyatakan evaluasi dilakukan diakhir semester. Ini menunjukkan adanya perbedaan ungkapan yang membuktikan kegiatan evaluasi belum terlaksana sebagai mestinya. Maka dapat diketahui bahwa guru menyadari akan adanya masalah evaluasi yang belum terlaksana. Karena evaluasi merupakan kegiatan identifikasi untuk melihat apakah suatu program telah tercapai atau belum, berharga atau tidak, serta dapat pula digunakan untuk melihat tingkat efisiensi dalam pelaksanaannya. (Astiti, 2017, hlm. 2).

Dari beberapa permasalahan tersebut sebenarnya dari ketiga partisipan mengetahui permasalahan tersebut dalam menyelenggarakan pendidikan inklusif, namun untuk mengatasi permasalahan tersebut dari ketiga partisipan belum mengungkapkan hal yang signifikan.

\subsubsection{Tantangan Dalam Menangani ABK}

Kemudian beralih pada isu lain dalam penyelenggaraan pendidikan inklusif, bahwa bukan hanya masalah yang ada dalam menyelenggarakannya saja, akan tetapi adanya tantangan dalam menangani ABK. Pada sub-tema ini akan disebutkan beberapa tantangan dalam menangani ABK diantaranya: kebutuhan ABK yang berbeda, kerjasama orangtua dan perekrutan SDM yang siap.

Pertama, kebutuhan ABK yang berbeda. Ketika berbicara mengenai penanganan ABK maka banyak sekali hal-hal yang menjadi bahan pertimbangan dikarenakan jenis kasus yang beragam sehingga kebutuhan setiap ABK berbeda. Oleh karena itu, pada pembahasan pertama yang menjadi tantangan guru dalam menangani $\mathrm{ABK}$ adalah untuk memenuhi kebutuhan ABK.

Dari peryataan ibu $\mathrm{H}$ diatas bahwa haruslah dilakukannya observasi terlebih dahulu untuk mengetahui kebutuhan anak. Selain itu pernyataannya memperlihatkan bahwa kebutuhan anak sangat berkaitan dengan kemampuan yang dimiliki anak dan pada $A B K$ ini dapat dikategorikan menjadi dua yaitu: anak yang mampu latih adalah anak yang lebih cenderung kemampuannya pada minat dan bakat yang dimilikinya, dan anak yang mampu didik adalah anak yang cenderung kemampuannya dapat 
berkembang dengan di didik secara berulang-ulang.

Maka pernyataan tersebut, guru memahami bahwa dalam menangani ABK harus sesuai dengan kebutuhan dan kemampuan anak. Namun keadaan sekolah inklusif di Indonesia saat ini disampaikan pada seminar umum bahwa sebagian besar guru reguler/umum masih melakukan strategi pembelajaran yang tidak jauh berbeda dengan pembelajaran anak-anak pada umumnya di sekolah inklusif, mereka masih kurang memperhatikan keterbatasan dan kebutuhan siswa yang berkelainan/berkebutuhan pendidikan khusus. Sama halnya menurut Suparno (2010, hlm. 6) bahwa dalam pendidikan inklusif sistem pendidikan yang menyesuaikan kebutuhan anak, dan bukan sebaliknya anak yang harus menyesuaikan diri dengan sistem yang ada di sekolah. Namun tantangan ini diatasi sekolah dengan melakukan pretest dan observasi diawal ketika trail yang dilakukan oleh psikolog langsung untuk mengetahui kemampuan dan kebutuhan anak sehingga dibuatlah rancangan pembelajaran untuk masingmasing ABK.

Kedua, kerjasama orangtua. Ibu $\mathrm{H}$ mengungkapkan hal lain dalam tantangan selanjutnya yaitu kerjasama orangtua yang sulit dilakukan. Sedangkan peran orangtua sangat diperlukan dalam merencanakan dan melaksankan program-program pendidikan di sekolah, seperti dalam mengambil kebijakan, mengembangkan kurikulum, ketenagaan, sarana-prasarana sehingga itu menjadi tanggung jawab bersama antara orangtua dan sekolah (Suparno, 2019, hlm.10).

Dari kedua pernyataan tersebut dapat diketahui bahwa kerjasama orangtua merupakan tantangan bagi guru dalam menangani ABK. Tapi dari hasil analisis dapat diketahui juga bahwa bentuk kerjasama yang sulit ini dikarenakan orangtua yang tidak terbuka dengan keadaan anaknya dan orangtua yang tidak mudah menerima keadaan anaknya sehingga hal tersbeut berdampak pada perkembangan anaknya. Namun pihak sekolah telah melakukan cara untuk mengatasi hal tersebut dengan adanya pendampingan psikolog yang melakukan pre-test dan observasi untuk mengetahui keadaan anak tersebut sehingga adanya data jelas yang dapat disampaikan kepada orangtua. Dari tantangan pertama dan kedua, pihak sekolah mengatasinya dengan pre-test dan observasi karena itu merupakan cara untuk membuktikan pada orangtua sehingga pihak sekolah dapat menyampaikannya dengan dukungan data dan pendampingan psikolog.

Sehingga dapat diketahui bahwa bukan hanya karena orangtua yang menutupi atau tidak menerima akan tetapi kerjasama dalam pemberian stimulus pun masih sulit dikarenakan kesibukan orangtua yang bahkan tidak dapat terlibat dalam pemberian stimulus. Guru pun sudah menyadari akan tantangan ini sehingga mereka dari hasil pre-test dan observasi maka diketahui kekhususan anak tersebut dan dibuatlah program khusus bersama dengan psikolog sehingga program tersebut dapat disampaikan kepada orangtua dan yang dapat dilakukan pihak sekolah adalah mengkomunikasikan hasil yang didapat kepada orangtua lalu menyampaikan program khusus yang sudah dirancang perlu bantuan dari orangtua agar penanganan ABK lebih optimal. Di dalam kontek pendidikan inklusif, peran orangtua dan masyarakat merupakan bagian yang integral dalam mencapai keberhasilan sesuai tujuan pendidikan yang direncanakan secara optimal.

Maka dapat dikatakan bahwa guru dapat mengatasi tantangan kerjasama orangtua dengan cara pembuktiaan data jelas dari psikolog, program khusus yang dirancang untuk masing-masing ABK, dan yang paling utama adalah komunikasikan yang baik dengan 
orangtua dengan tidak ada unsur diskriminasi.

Ketiga, perekrutan SDM yang siap. Dan pembahasan terakhir pada subtema ini adalah perekrutan SDM yang siap, bukan hanya menjadi permasalahan dalam menyelenggarakan pendidikan inklusif tapi dalam penanganan $\mathrm{ABK}$ pun menjadi tantangan karena untuk ABK, guru yang mendampingi haruslah yang memiliki pemahaman penuh mengenai penanganan ABK. Akan tetapi keadaan di lapangan berbanding terbalik dengan yang seharusnya.

Seperti ungkapan ibu $\mathrm{H}$ bahwa guru pembimbing khusus atau shadow teacher/helper merupakan tantangan dalam perekrutannya dikarenakan untuk merekrut SDM yang siap maka itu, mereka yang berlatar belakang pendidikan khusus tetapi sulit ditemukan karena keberadaan SDM yang siap lebih memilih untuk mendampingi di sekolah luar biasa (SLB) bukan sekolah penyelenggara inklusi.

Dalam Buku Pedoman Pembinaan Tendik Direktur PSLB (2007) menyatakan bahwa perekrutan GPK (guru pembimbing khusus) terdapat tiga anternatif yaitu: pertama, melalui kerjasama guru SLB terdekat; kedua, merekrut guru dengan kualifikasi PLB dan guru reguler yang memproleh pelatihan tentang $\mathrm{ABK}$ dan ketiga, dari klinik-klinik pendidikan atau pusat pengembangan anak. Namun pihak sekolah lebih memilih perekrutan GPK dengan latar belakang pendidikan SMA karena kembali lagi pada masalah penyelenggaraan inklusif di Indonesia, bahwa SDM yang ada sangat terbatas dan ini berkaitan pula dengan keadaan ekonomi orangtua $\mathrm{ABK}$ sehingga perlu adanya keterlibatan orangtua dalam mendukung dana GPK yang ada.

Pembahasan diatas dapat disimpulkan bahwa guru menyadari akan adanya tantangan sekolah dalam menangani ABK sehingga mereka pun dapat mengatasinya dengan bebagai cara diantaranya: mengadakan pembinaan oleh psikolog, adanya kegiatan parenting, komunikasi dengan orangtua, dan mengadakan kegiatan sesuai dengan kebutuhan ABK yang disesuaikan dengan kemampuannya. Artinya guru sudah memiliki salah satu kemampuankemampuan yang memang harus dimilikinya, yaitu: pemahaman tentang "Konvensi Hak Anak" dan implikasinya terhadap implementasi pendidikan dan perkembangan semua anak.

\subsection{Treatment Anak Berkebutuhan Khusus}

Tema kedua dalam pembahasan ini mengungkap berbagai treatment yang digunakan untuk menangani $\mathrm{ABK}$ di PAUD inklusi berbasis alam. Fawzia (2007) menjelaskan, bahwa diyakini pengaruh paling mengena dan dapat meninggalkan kesan yang lama harus dilakukan pada saat yang tepat yaitu pada masa kritis atau masa sensitif. Perlunya rangsangan diberikan pada usia dini yang dapat meningkatkan seluruh aspek perkembangan juga didasarkan pada pandangan tersebut.

Keterlambatan atau pengabaian rangsangan pada saat yang tepat atau pada periode kritis akan memberi dampak negatif bagi perkembangan anak. Hal ini terlihat dari jawaban guru ketika ditanyai pentingnya pendidikan inklusi sejak dini, seperti pernyataan berikut:

"Euu.. semua anak butuh eu.. apa semua anak mempunyai ciri khas masingmasing jadi tidak, tidak apa yah tidak ada yang dibeda-bedakan untuk ditangani semua anak wajib kita bantu baik yang berkebutuhan khusus ataupun tidak dimanapun siapapun ya mendapatkan perlakuan yang sama. Jadi semakin dini kita tangani anak yang berkebutuhan khusus akan mengurangi, tidak bisa mengilangkan atau menyembuhkan tapi mengurangi apa yang menjadi gejala beratnya".

(Wawancara M, 12 Juli 2019) 
"Kalo menurut saya itu penting karena kalo untuk anak-anak yang berkebutuhan khusus еии mulai diterapkan lingkungan sekitarnya itu sangat pentinglah biar dia ga ngerasa beda gitu dari yang lain terus di dalam satu kelas itu kan emang ga di bedabedain jadi dia merasa dihargain disini dia merasa nyaman sama lingkungan sekitarnya jadi ga ngerasa minder."

(Wawancara M, 12 Juli 2019)

Pernyataan ini menjadikan kita tahu akan penanganan sejak dini, bukan sejak dini itu ketika usia PAUD namun sedini mungkin dilakukan terapi atau stimulus yang dibutuhkannya sehingga akan mengurangi gejala berat semakin besar dan itu berdampak pada perkembangannya sehingga ketika memasuki usia sekolah mulai dari PAUD, ABK tersebut sudah dapat bergaul dengan teman-temannya meskipun tetap akan terlihat perkembangannya lebih lambat.

Dari data hasil wawancara yang telah dilakukan diketahui beberapa hal sekolah dalam melakukan penanganan untuk $\mathrm{ABK}$, diantaranya: pre-test dan observasi oleh psikolog, program khusus, pendampingan green therapy, dan terapi 24 jam.

Pertama, pre-test dan observasi oleh psikolog. Dari tema sebelumnya bahwa tahap awal dalam menangani ABK adalah mengetahui kekhususan yang dimilikinya dengan mengadakan pre-test dan observasi yang dilakukan oleh psikolog sebagai orang yang ahli dalam bidang tersebut.

"Euuu. kita itu ada progresnya sebelum penerimaan siswa baru, jadi kita liat dulu anaknya, di observasi karna kan tidak seтиa terlihat yah, karena itu bagian dari psikolog juga. Di observasi anaknya sama gurunya setelah itu еиии.. poin-poinnya ada, kira-kira ini poin anak normal maksudnya ini kalo ada kendala "ini ko aneh sih anaknya", nah ada penilaian observasi anak spesial. Nah kalo itu dinyatakan ketika ada ceklis di anak spesial kita amati lagi, kemudian ada pre-test lalu dinyatakan misalnya speech delay atau apa, kemudian itu ada saran dari psikolognya, satu saran terapi kemudian yang keduanya yaitu itu harus еиии.. kerjasama dengan pihak sekolah dan itu ada juga euuu.. pendampingan dari psikolognya jadi kalo ada orang tua yang bingung anaknya harus digimanain boleh nih konsultasi dengan psikolognya tapi itu terjadwal".

(Wawancara H, 22 Juni 2019)

Sehingga dari pernyataan tersebut dapat diketahui adanya pre-test dan observasi sebelum penerimaan siswa baru. Selain itu dapat terlihat pula proses yang terjadi mulaii dari observasi yang dilakukan oleh psikolog untuk melihat keadaan semua anak. Observasi ini dilakukan hanya satu hari ketika anak mengikuti trail atau kegiatan belajar seperti biasanya.

Dari hasil obsrvasi maka akan dilakukan pre-test, dimana tes awal ini dilakukan oleh psikolog dan untuk prosesnya hanya psikolog yang tahu. Kemudian dengan adanya data dari observasi dan pre-test maka psikolog mendiagnosa kekhususan yang dimiliki ABK serta menyarankan pendampingan atau tidak dan menyarankan stimulus yang diberikan. Selain itu dalam penyampaian kepada orangtua psikolog turut serta dalam mengkomunikasikannya karena dengan bantuan psikolog, orangtua yang menutupi atau pun yang tidak mau terima akan lebih mudah menerima dan mengetahui apa yang harus dilakukannya.

Maka dapat diketahui untuk menangani $\mathrm{ABK}$ perlu adanya pre-test dan observasi oleh orang yang memang ahli dibidangnya agar guru-guru yang ada mengetahui tindakan apa yang harus dilakukan dalam menangani ABK. Hasilnya dapat digunakan sebagai 
penyusunan program khusus sesuai dengan kekhususan ABK masing-masing.

Kedua, program khusus. Program khusus merupakan program yang berisi stimulus yang akan diberikan pada ABK dengan kata lain program khusus ini dapat dikatakan sebagai kurikulum khusus/PPI untuk ABK yang telah dirancang khusus dan dimodifikasi sesuai dengan kebutuhan ABK. Kurikulum yang diterapkan, dapat dikembangkan sekolah sesuai dengan standar kompetensi untuk anak-anak normal secara penuh, modifikasi, atau secara khusus dikembangkan program pembelajaran individual (PPI) bagi ABK (Suparno, 2010, hlm.15).

Dapat diketahui dari kedua pernyataan tersebut bahwa program khusus ini disusun oleh psikolog dan kepala sekolah untuk tiga bulan lamanya. Dilakukan selama 3 bulan bertujuan untuk mengetahui keberhasilan dari program yang telah dirancang sehungga akan dilakukan evaluasi untuk mengetahui stimulus yang telah diberikan meberikan hasil yang optimal atau tidak. Sesuai dengan teori sebelumnya bahwa kurikulum yang ada dapat di modifikasi sesuai dengan kebutuhan anak.

Ketiga, pendampingan Green therapy. Green therapy ini merupakan metode yang baru diterapkan pada sekolah alam tersebut, setelah mencari penanganan yang sesuai, pihak sekolah akhirnya mencoba green therapy yang memang pada sekolah alam lain telah diterapkan. Awalnya ibu $\mathrm{H}$ mengetahui green therapy ini dari sekolah alam Batu Raden yang memang sudah lama menerapkan metode tersebut. Namun untuk menerapkan metode ini haruslah didukung dengan fasilitas atau lingkungan sekolah yang memang bermuatan.

Dari pernyataan ibu $\mathrm{H}$ ini dapat diketahui bahwa pengaruh alam sangat besar untuk konsentrasi anak. Dan model yang digunakan adalah green therapy sesuai dengan sekolah yang berbasis alam. Dimana stimulus yang diberikan berkaitan dengan alam karena alam sangat mempengaruhi konsentrasi dan kesehatan anak. Lingkungan alam bermanfaat baik itu fisiologis dan psikologis, termasuk perhatian, dan bau alami berpengaruh untuk meningkatkan status afektif yaitu: ketenangan, kewaspadaan dan suasana hati.

Dengan teori yang ada mengenai manfaat alam dan pernyataan ibu $\mathrm{H}$, maka pemberian stimulus atau terapi yang dilakukan tidak harus dengan ruangan yang tertutup dan sendirian namun dilakukan di alam pada tempat yang terbuka maka kegiatan tidak akan membuat anak tersebut menjadi bosan dan tidak terlihat seperti terapi.

"Itutuh biar euuu.. mencegah anaknya gabosen gitu jadi ga stuck disitu situ aja besoknya ada stimulus lain gitu yang bikin anaknya tuh ga ko bosen yah tiap hari itu terus itu terus dikasihnya jadi dibikin apa yah kaya semacam permainan gitu jadi anaknya enjoy gitu ngerjainnya"

(Wawancara T, 12 Juli 2019)

Pernyataan ibu $\mathrm{T}$ ini pun memperlihatkan adanya stimulus yang diberikan bermacam-macam setiap hari nya dan tidak dalam kondisi dipaksakan sehingga anak merasa seperti sedang bermain. Selain itu aktivitas outdoor akan menstimulasi indra proprioseptif (kinestetik) yang dapat memberikan efek penanganan pada sistem saraf anak, terutama saat musim dingin.

Udara yang dingin/segar dapat membantu sistem modulasi pengaturan aliran impuls dari kulit yang sering dapat menurunkan hiperaktivitas. Dalam pengambilan data pun diketahui bahwa green therapy ini memiliki rapot khusus yang digunakan sebagai penilaian perkembangan ABK. Rapot khusus tersebut berisikan narasi GPK mengenai kelebihan dan kekurangan $\mathrm{ABK}$ dan kegiatan $\mathrm{ABK}$ setiap harinya. 
Dari analisis setiap pernyataan tersbeut bahwa sekolah memiliki oendmapingan green therapy namun belum berjalan seharusnya dikarenakan masih dalam tahap percobaan. Namun diketahui pula adanya stimulus-stimulus yang sudah berkaitan dengan alam seperti berjalan diatas rumput atau kerikil tanpa menggunakan alas kaki. Akan tetapi untuk penilaian $\mathrm{ABK}$ green therapy ini memiliki rapot khusus.

Keempat, terapi 24 jam. Adanya terapi 24 jam dimana terapi ini dilakukan tidak hanya di sekolah namun di rumah pun dilakukan dengan adanya keterlibatan orangtua sehingga perkembangan anak dapat optimal. Bahwa terapi 24 jam ini dikatakan PR, karena dilakukan di rumah dengan pemberian stimulus yang berkaitan dengan keterampilan dalam mengurus diri karena ABK harus memiliki bekal kemandirian. dan terapi 24 jam ini sesuai dengan pernyataan ibu $\mathrm{H}$ dan ibu $\mathrm{M}$ bahwa biasanya guru memberikan catatan untuk orangtua dalam memberikan stimulus di rumah karena untuk $\mathrm{ABK}$ perlu adanya keseimbangan pembiasaan stimulus baik di sekolah maupun di rumah. Pada terapi 24 jam ini pun adanya penilaian PR seperti laporan setiap hari dari GPK untuk orangtua berupa saran stimulus di hari biasa namun untuk menyeimbangi hari libur maka PR yang diberikan lebih banyak.

Bahwa stimulus dapat dilakukan dengan cara mencontohkan terlebih dahulu dan pengulangan kata untuk yang speech delay, selain itu stimulus yang diberikan bukan hanya berupa fisik tapi stimulus lain pun dapat dilakukan dengan mengadakan worksheet. Worksheet ini biasanya dilakukan GPK dalam memberikan stimulus konsentrasi karena tidak hanya dari GPK namun dari fasilitator pun ada dan ini biasanya dilakukan ketika di dalam kelas.

\section{SIMPULAN}

Bahwa dalam menyelenggarakan pendidikan inklusif banyak masalah yang akan di hadapi yaitu fasilitas dan SDM yang masih kurang, pembiayaan dan evaluasi pendidikan inklusif sendiri. Selain masalah adapun tantangan yang dihadapi seperti kesibukan orangtua namun dapat diatasi dengan adanya PR stimulus dan komunikasi yang baik antar guru dan orangtua serta danya tatatertib berupa komitmen orangtua dalam mematuhi aturan sekolah, perekrutas SDM yang sulit namun dapat diatasi dengan merekrut lulusan SMA karena berkaitan dengan salary dari orangtua, serta kebutuhan ABK yang berbeda namun dapat diatasi dengan adanya pendampingan psikolog yang melakukan pre-test dan observasi untuk mengetahui kebutuhan ABK.

Lalu ditemukan adanya treatment ABK dengan melakukan pre-test dan observasi oleh psikolog, adanya program khusus atau PPI, adanya gren therapy namun masih dalam tahap percobaan, dan adanya terapi 24 jam yang dilakukan agar adanya keterlibatan orangtua.

\section{DAFTAR RUJUKAN}

Astati, dkk. (2013). Pendidikan Anak Berkebutuhan Khusus. Bandung: Universitas Pendidikan Indonesia.

Badan Pusat Statistik. 2017. Persentase Penduduk Usia 7-24 tahun Menurut jenis Kelamin, Kelompok Umur Sekolah, dan Partisipasi Sekolah, 2002-2016. 23 November. Diakses dari https://www.bps.go.id/statictable/ 2014/09/05/1533/persentasependu duk-usia-7-24-tahun-menurutjenis-kelamin-kelompok-umursekolah-dan-partisipasi-sekolah-12002-2016.html

Creswell, J. W. (2010). Research design: pendekatan kualitatif, 
kuantitatif, dan mixed. Yogjakarta: PT Pustaka Pelajar.

Fawzia, A.H. (2003). Perkembangan dalam Perspektif Pendidikan Anak Usia Dini. Buletin PAUD, 2(1).

Florian, L. (2008). Special or inclusive education: future trends. British Journal of Special Education, 35(4), 2002-207.

Hornby, G. (2015). Inclusive special education: development of a new theory for the education of children with special educational needs and disabilities. British Journal of Special Education, 43 (3), doi: 10.1111/1467$\underline{8578.12101}$

Johnsen, B.H. \& Skjorten, M.D. (2003). Pendidikan Kebutuhan Khusus Sebuah Pengantar. Bandung: Sekolah Pasca Sarjana UPI.

Maulipaksi, D. (2017). "Sekolah Inklusi dan Pembangunan SLB Dukung Pendidikan Inklusi”. Diakses dari:

https://www.kemdikbud.go.id/mai n/blog/2017/02/sekolah-inklusidan-pembangunan-slbdukungpendidikan-inklusi.

Mulyani, G. (2016). Pelaksanaan Tugas Furu Pendidik Khusus di Sekolah Penyelenggara Pendidikan Inklusif. Jurnal Ilmiah Pendidikan Khusus, 5(1). http://ejournal.unp.ac.id/index.p $\mathrm{hp} / \mathrm{jupekhu}$

Peraturan Menteri Pendidikan dan Kebudayaan Nomor 146 tahun 2014 tentang Kurikulum 2013 Pendidikan Anak Usia Dini.

Peraturan Menteri Pendidikan Nasional Nomor 70 Tahun 2009 tentang
Pendidikan Inklusif bagi Peserta Didik yang Memiliki Kelainan dan Memiliki Potensi Kecerdasan dan/atau Bakat Istimewa.

Peraturan Pemerintah Nomor 17 Tahun 2010 tentangPengelolaan dan Penyelenggaraan Pendidikan.

Peraturan Presiden Nomor 60 Tahun 2013 tentang Pengembangan Anak Usia Dini Holistik-Integratif.

Sukmadinata, N.S. (2007). Metode Penelitian Pendidikan. Bandung: Rosdakarya.

Suparno, M. Y. (2009). Keterampilan Dasar Menulis. Jakarta: Universitas Terbuka.

Tarnoto, N. (TT). Permasalahanpermasalahan yang Dihadapi Sekolah Penyelenggara Pendidikan Inklusi Pada Tingkat SD. Humanitas, 14(1), 50-61.

Undang-Undang Nomor 20 tahun 2003 tentang Sistem Pendidikan Nasional.

UNESCO. (1994). The Salamanca Statement And Framework For Action On Special Needs Education. World Conference On Special Needs Education: Access And Quality. Salamanca, Spain, 7-10 June 1994 http://www.unesco.org/education/ pdf/SALAMA_E.PDF 